解

説

焼結力学のマルチスケールモデル

\author{
若井 史博
}

東京工業大学応用セラミックス研究所セキュアマテリアル研究センター，～２26-8503 横浜市緑区長津田町 4259-R3-23.

\title{
Multi-scale Modeling of Sintering Mechanics
}

\section{Fumihiro WAKAI}

Secure Materials Center, Materials and Structures Laboratory, Tokyo Institute of Technology, R3-23 4259 Nagatsuta, Midori-ku, Yokohama 226-8503, Japan.

Received July 20, 2012

\begin{abstract}
Many sintering bodies shrink in an anisotropic manner when the particle packing is not isotropic. In the continuum mechanics frame work, macroscopic shrinkage in sintering is described as a linear function of the sintering stress tensor and the viscosity tensor. These macroscopic quantities are determined rigorously from local microstructure and microscopic kinetics involving grain boundary diffusion. The shrinkage is driven by the hydrostatic component of the sintering stress tensor, while the anisotropic deformation is driven by its deviatoric components. This model is able to predict both the evolution of the anisotropic microstructure during sintering, and also the effect of the local microstructure on anisotropic shrinkage.
\end{abstract}

KEY WORDS

sintering, simulation, sintering stress, shrinkage

\section{1 巨視的スケールの連続体力学}

焼結は成形した粉体を加熱して複雑形状部品を製造する技 術である. 長い歴史を通じて発展し, 基礎理論の学問的な枠 組みは 1960 年代にほぼできあがった ${ }^{1,2)}$ 。焼結は一般に緻密 化, つまり, 相対密度が時間とともに増加する現象として理 解されている. 一方, 1980 年代後半からは焼結を収縮, つま り, 連続体力学にもとづいた高温変形として扱うアプローチ が始まり，新たな発展を遂げている.

連続体力学の線形理論では, 焼結のひずみ速度は外部から 加えられた機械的応力と緻密化の熱力学的駆動力の一次関数 として表わされる ${ }^{3-7)}$. 粉体成形により複雑形状の成形体が得 られるが, 密度分布の不均一のため, あるいは, 部材形状に 起因して焼結中の収縮が一様でなくなる(Fig. 1(a)). 連続体理 論は収縮挙動を予測し, 製品の品質・形状および寸法精度を 保証するのに役に立つ。

特に, 場所によって収縮速度が異なる拘束焼結 (constrained sintering) ${ }^{3}$ や共焼結(co-sintering)のような複雑な問題を解析す る上で強力な手法となる ${ }^{8)}$. 例えば, 第2 相粒子や強化繊維が 分散した複合材料の焼結, 電極などを埋め込み複合化したデ
バイス, 基板上の薄膜, 低温同時焼成セラミックス (Low Temperature Co-fired Ceramics, LTCC) や固体酸化物燃料電池 (SOFC)などの積層材料では, 収縮速度の違いによって部材の 内部に引張応力が発生して焼結が阻害され, 場合によっては, キャビティやクラックの発生, 剥離が起こり, 部材のゆがみ

(a)

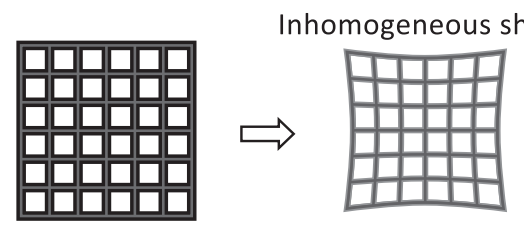

(b)

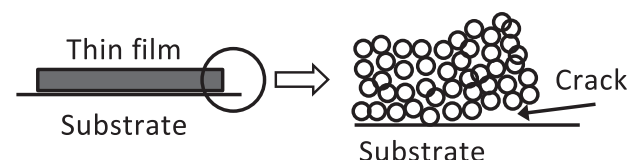

Fig. 1 Schematic illustrations of structures that densify at different rates. (a) A porous component that has density variations, (b) Crack formation at the edge in constrained sintering of a thin film on the substrate. 
を引き起こす(Fig. 1 (b)). 連続体理論に基づいた有限要素法シ ミュレーションを行えばこのような焼結中の応力場や部材の 変形を予測できる7.9.

1.1 等方的構成方程式

等方的な場合, 焼結による変形のひずみ速度 $\dot{\varepsilon}_{i j}$ は応力の関 数として次式で表現できる3-7).

$$
\dot{\varepsilon}_{i j}=\frac{\sigma_{i j}^{\prime}}{2 G}+\delta_{i j} \frac{\sigma^{m}-\sigma^{s}}{3 K}
$$

ここで, 応力は静水圧成分 $\sigma^{m}$ と偏差成分 $\sigma_{i j}^{\prime}$ に区別する， $\sigma^{s}$ は焼結力, $G$ はせん断粘性率, $K$ は体積粘性率, $\delta_{i j}$ はクロネッ カーのデルタである. (1)式の右辺第 1 項は体積変化をともな わないせん断変形を引き起こし, 右辺第 2 項が体積変化をも たらす. 外部から応力が働かなくても自発的に収縮が起こる のは, 焼結応力 (焼結圧力) $\sigma^{5} か ゙$ 働くからであり,これが狫結 の熱力学的駆動力である.ここで, $\sigma$ の符号は応力と逆であ ることに注意する. 応力は引張りを正とするが, 圧力は圧縮 が正だからである. 緻密化速度 $\dot{\rho}$, つまり, 相対密度 $\rho$ の時 間変化はひずみ速度で表すことができる。

$$
\dot{\rho} / \rho=-\operatorname{trace}\left(\dot{\varepsilon}_{i j}\right)
$$

(1) 式でひずみ速度 $\dot{\varepsilon}_{i j}$ をひずみ $\varepsilon_{i j}$ に置き換えると, 弾性論の 基本方程式と類似していることがわかる. そこで，等方弾性 体と同様, 一軸粘性率 $E$ (ヤング率に相当) と粘性ポアソン比 vで表すこともできる.

$$
\begin{aligned}
& E=\frac{9 G K}{G+3 K} \\
& v=\frac{3 K-2 G}{6 K+2 G}
\end{aligned}
$$

これらのパラメーターは定数ではなく, 焼結中の微細組織と ともに変化する変数である. 有限要素法シミュレーションに は, 相対密度の関数として理論的あるいは半経験的に求めら れた近似式が便宜的に用いられる》。しかし，収縮を精密に 予測するには, 実験的に, $\sigma, E, v$ を相対密度の関数として決 定する必要がある.

\section{2 焼結鍛造試験}

Fig. 2に示すように, 試験片を一軸加圧し, 焼結と同時に圧

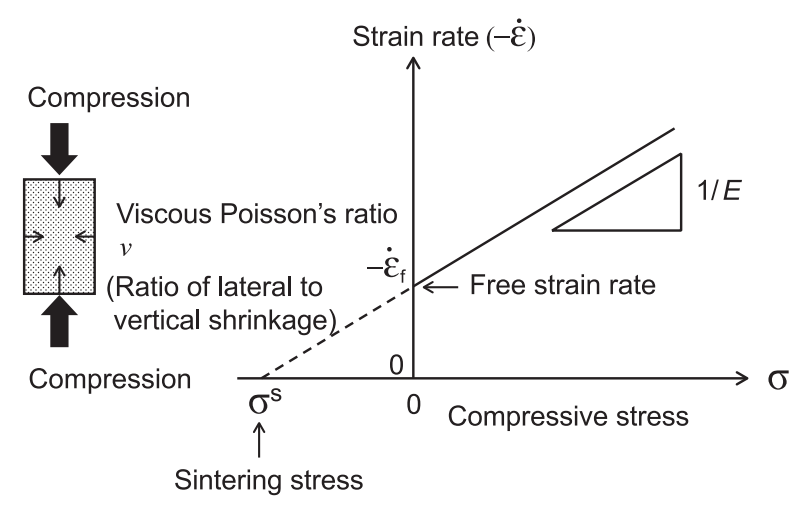

Fig. 2 Schematic illustration of sinter forging experiment.
縮変形させる試験を考える. 圧縮応力を加えると，外力のな い場合の自由焼結ひずみ速度 $\dot{\varepsilon}^{f}$ よりも速いひずみ速度で変形 する. Fig. 2の直線の勾配から $1 / E か ゙$ 決定でき, 直線と応力軸 との交点から燒結応力が求まる. また, 横方向と縦方向の収 縮量の比から $v$ が測定できる. この方法は, 焼結鍛造 (sinter forging) 試験, あるいは熱間鍛造 (hot forging) 試験之呼ばれて いる.

Fig. 3には例としてアルミナ $\left(\mathrm{Al}_{2} \mathrm{O}_{3}\right)$ の熱間鍛造試験 ${ }^{10}$ によ る $v$ の実測值を示した. 相対密度とともに, $v$ はしだいに増 加する. 完全に緻密な材料に応力を加えて変形させても体積 は一定なので, $v$ は 0.5 である. 圧縮応力により多孔体が収縮 できるとき，vは 0.5 よりも小さい，一般的に $\sigma^{s}, E, v$ 等の巨 視的パラメーターは相対密度とともに増加するが, その挙動 は原料の種類, 成形法, 焼結助剤, 焼結温度, 焼結中の粒成 長に影響される。ささまざまな原料粉体に対して巨視的パラ メー夕を実験的に決定する必要があるが, これには多大の労 力を要することが問題点である.

1.3 異方性を考慮した焼結の連続体力学

巨視的な収縮挙動は相対密度だけでなく, 粒子スケールの 局所構造に依存する. つまり, 原料粉体の形状や粉体成形プ ロセスによる初期粒子配置によって焼結挙動は大きく影響さ れる.ところが, 粒子は不規則な形状をしており, しばしば プレス成形, 射出成形, 鋳込み成形などの粉体成形の際に粒 子配向がおこる. たいていの場合, 収縮は完全に等方的でな く, 実は異方的である ${ }^{111}$. また, 拘束焼結や共焼結では焼結 中に部材内部に発生する応力によって微構造が異方的に変化 する. 2000 年代の半ばには焼結の連続体力学に異方性を取り 入れることの必要性が認識されるようになった ${ }^{8,121}$. 異方性をとり入れた焼結の構成方程式は以下のように表され $ろ^{4}$.

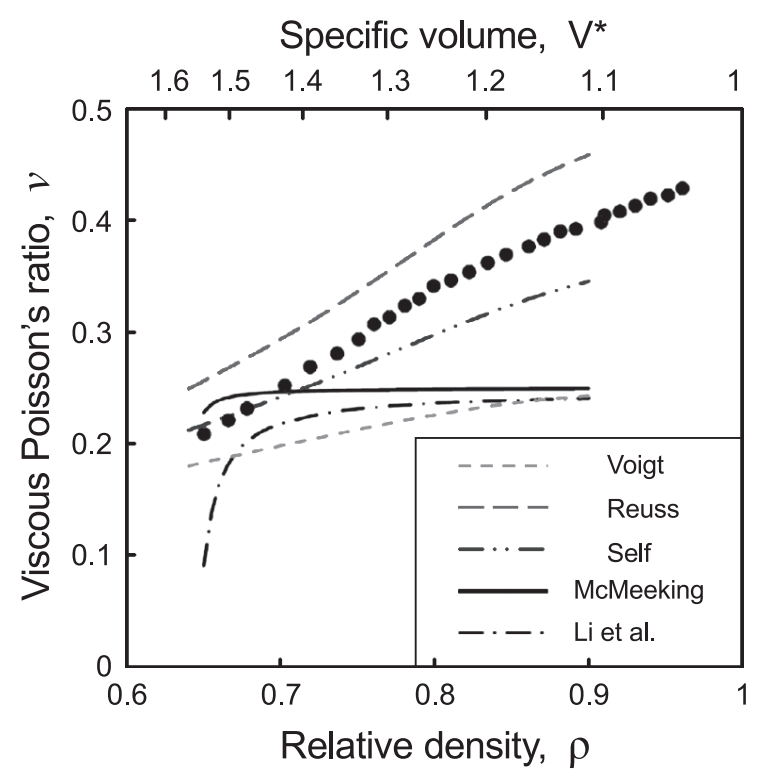

Fig. 3 Comparison of measured viscous Poisson's ratio with those predicted by theoretical model $\mathrm{s}^{25}$. Filled circles show Zuo et al.'s experimental results for $\mathrm{Al}_{2} \mathrm{O}_{3}$ at $1250^{\circ} \mathrm{C}^{10)}$. 


$$
\sigma_{i j}=\sigma_{i j}^{s}+C_{i j k m} \dot{\varepsilon}_{k m}
$$

ここで, 添字の和に関する縮約記法を用いた， $C_{i j k m}$ は粘性テ ンソル, $\sigma_{i j}^{s}$ は焼結応力テンソルである. マトリックス表示で は次のようになる.

$$
\sigma_{i}=\sigma_{i}^{s}+C_{i j} \dot{\varepsilon}_{j}
$$

ここで, 添字を以下のように置き換えた $11 \rightarrow 1,22 \rightarrow 2,33$ $\rightarrow 3,(23,32) \rightarrow 4,(13,31) \rightarrow 5,(12,21) \rightarrow 6$.

(6) 式は以下のようにも変換できる ${ }^{13)}$.

$$
\dot{\varepsilon}_{i}=\dot{\varepsilon}_{i}^{f}+S_{i j} \sigma_{j}
$$

ここで, $S_{i j}$ は粘性コンプライアンステンソル, $\dot{\varepsilon}_{i}^{f}$ は自由焼結 ひずみ速度である. 粘性テンソルと粘性コンプライアンステ ンソルとの間には $S_{i j}=C_{j k}=C_{i j} S_{j k}=\delta_{j k}$ の関係がある. 自由焼 結ひずみ速度は焼結応力により決定される.

$$
\dot{\varepsilon}_{i}^{f}=-S_{i j} \sigma_{j}^{s}
$$

Bordia ${ }^{12)}$ は $i, j=1,2,3$ に対して(7)式を以下のように表した.

$$
\dot{\varepsilon}_{i}=\dot{\varepsilon}_{i}^{f}+\frac{\sigma_{i}}{E_{i}}-\frac{v_{j i}}{E_{j}} \sigma_{j}
$$

ここで, 粘性コンプライアンスと一軸粘性係数, 粘性ポアソ ン比との間には以下の関係がある.

$$
\begin{array}{ll}
\text { 一軸粘性係数 } & E_{i}=1 / S_{i i} \\
\text { 粘性ポアソン比 } & v_{j i}=-S_{i j} / S_{i i} \quad(i \neq j)
\end{array}
$$

以上のような構成方程式を用いれば, 拘束焼結における異 方的収縮などの複雑な問題を解析できる.ただし, 現状では, 焼結鍛造試験により実験的にすべてのパラメーターを決定す ることは不可能である. 異方的パラメーターの簡便な測定技 術を開発することが今後の課題である.

次節以降では微構造に関する知識をもとに構成方程式にお ける異方性パラメーターを理論的に推定する手法について述 ベる.

\section{2 ミクロスケールの焼結力学}

2.1 焼結の運動方程式

焼結の巨視的収縮は粉末成形体の微視的な構造に影響され る. 古典的な教科書では, ミクロスケールでの焼結は「粒子 間の結合の形成」と定義され，2球粒子焼結モデルでのネッ ク成長が解析されてきた ${ }^{1,2)}$.ここでは, ミクロスケールの収 縮の熱力学的駆動力が「焼結力」であり, 力に対する応答と して焼結を理解できることを示す。

2つの球粒子が接触して, 粒界拡散と表面拡散によって焼 結することを考える. 2粒子が焼結するとき, Fig. 4 に示すよ うに粒界には応力分布による化学ポテンシャルの勾配が生じ, ネック表面で生成した空孔が粒界に沿って拡散する. 空孔は, 結晶粒が相互に近づくことによって粒界で消失する. 粒子間 距離の収縮速度 $\dot{u}_{i}$ は以下の焼結の運動方程式で表される ${ }^{4,14-16)}$.

$$
\begin{aligned}
& \dot{u}_{i}=-F_{i}^{s} / K^{\prime} \\
& K^{\prime}=\pi x^{4} k T / 8 \Omega \delta D_{g b} \\
& F_{i}^{s}=\left(\gamma_{s} \kappa_{\text {neck }}-\bar{\sigma}\right) A_{g b} n_{i}
\end{aligned}
$$

ただし， $\gamma_{s}$ は表面エネルギー, $\Omega$ は原子体積, $k$ はボルツマン 定数, $T$ は絶対温度, $n_{i}$ は粒界の単位法線ベクトルである. 有 効粘性係数 $K^{\prime}$ はネック半径 $x$ の 4 乗に比例し, 粒界拡散係数 $\delta D_{g b}$ に反比例する. (14)式に示すとおり, 焼結力 $F_{i}^{s}$ は, ネッ ク表面の曲率 $\boldsymbol{\kappa}_{\text {neck }}$ による引張応力 $\gamma_{s} \kappa_{\text {neck }}$ 之粒界の平均圧縮応 力 $\bar{\sigma}=2 \gamma_{s} \sin (\psi / 2) / x$ との差から生じ, 粒界面積 $A_{g b}=\pi x^{2}$ に比 例する.ここで $\psi$ は2 面角であり, 粒界エネルギー $\gamma_{g b}$ と表面 エネルギーの比で与えられる $\left(\gamma_{g b}=2 \gamma_{s} \cos (\psi / 2)\right)$.

\section{2 離散要素法}

焼結では非常に膨大な数の粒子が相互作用する.あるひと つの粒子に着目すると, その粒子の粒界には隣接粒子から焼 結力が働いている. それぞれの粒子の運動は, それらの焼結 力に対する応答のベクトル和であるから, 分子動力学で原子 集団の挙動を予測するのと同様に, 焼結における粒子集団の 収縮をシミュレートできる，この方法は離散要素法 (Discrete Element Method, DEM) と呼ばれる. 例えば, Fig. 1 (b)のよう な薄膜の焼結において個々の粒子運動を追跡することによっ て, 基板との間にクラックが生じて剥離が起こる様子を再現 できる ${ }^{17)}$. DEM法では巨視的な構成方程式や異方的パラメー 夕を考えなくても, 粒子間に作用する焼結力だけから複雑な 焼結挙動を解析できる。

Fig. 5には2つの球粒子の焼結における焼結力をネック半径 の関数として示した ${ }^{16)}$. この場合, 焼結力はあるネック半径 で最大となり, さらに焼結が進行するにつれて減少し, 平衡 形状に到達すると焼結力がゼロとなり, 収縮は停止する. Martin ${ }^{18)}$ は焼結力がネック半径によらずほぼ一定であると 仮定してDEMシミュレーションを行った. 彼らのモデルは 2 球粒子間の焼結力を定数で近似したものに対応する。一方,

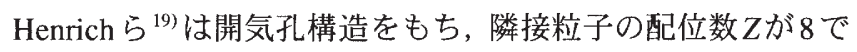
ある粒子の焼結力にもとづいてシミュレーションを行った. より精度の高い DEM シミュレーションのためには, 多数の 粒子間の相互作用まで含めた焼結力の解析が必要である.

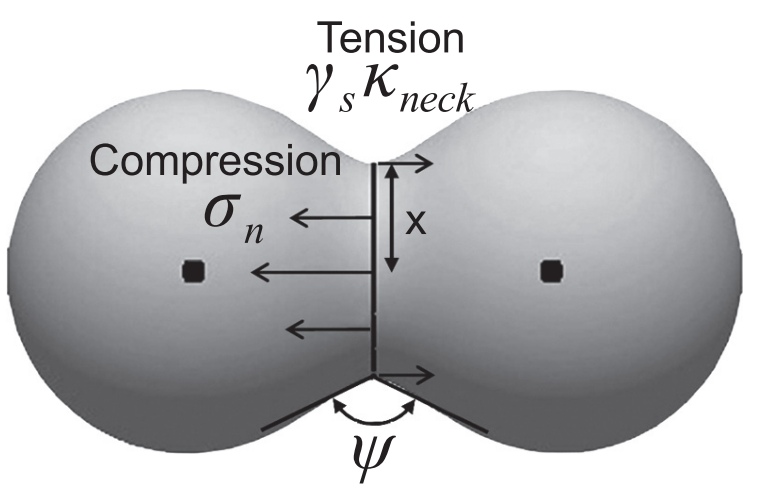

Fig. 4 Stress distribution at grain boundary in sintering of two particles by grain boundary diffusion. 


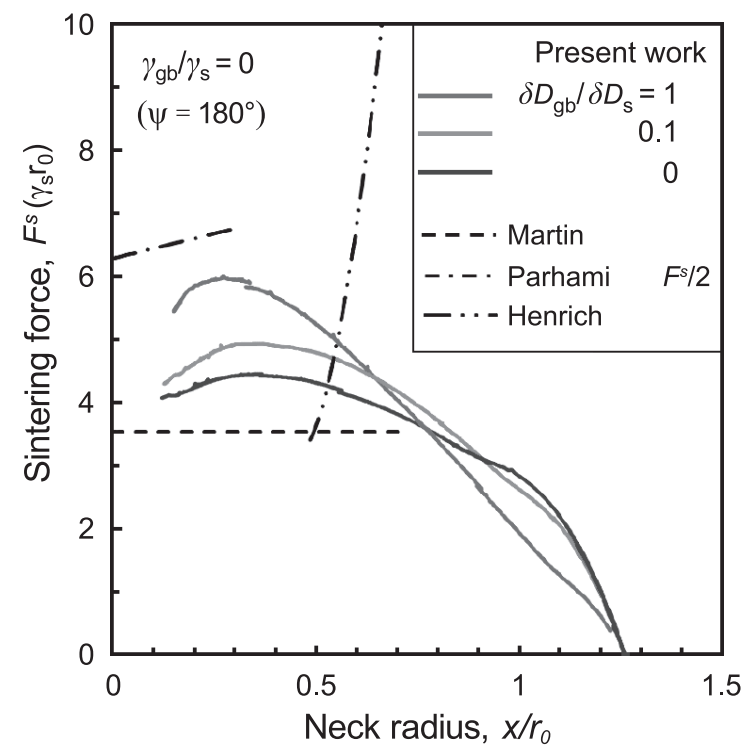

Fig. 5 Comparison of the sintering force vs. neck radius for various models ${ }^{16)}$.

\section{3 マルチスケールの焼結力学}

粒子スケールの構造や力学をもとに巨視的挙動を理論的に 予測できる. 理解を容易にするために, 中期焼結における微 構造を Fig. 6 に示すような表面曲率が一定の開気孔構造で近 似したモデル ${ }^{15,20-23)}$ を例にとって説明する. 体積要素の辺の 長さ $\mathrm{a}, \mathrm{b}, \mathrm{c}$ を変えることにより異方的な組織を表すことがで きる. 局所的な構造は粒子の配位数 $Z$ で区別できる.

\section{1 焼結応力}

Svoboda ら ${ }^{20)}$ は，ある粒子のすべての粒界面に作用する焼 結力ベクトルの総和から, 焼結応力テンソルを定義した.

$$
\sigma_{i j}^{s}=F_{i}^{s} / A_{j}
$$

ここで, $A$, は $O x_{j}$ 軸に垂直な面の面積， $F$ 、はこの面に作用す る焼結力ベクトルの $O x_{\imath}$ 軸方向の成分である.

一方, ある体積要素 $V$ に作用する焼結力の平均をとること によって, 焼結応力テンソルを表面曲率 $\kappa$ で表わせる ${ }^{22)}$.

$$
\begin{aligned}
\sigma_{i j}^{s}= & \frac{\gamma_{s} \kappa}{V^{*}} \delta_{i j} \\
& +\frac{1}{V}\left\{\int_{A_{s}} \gamma_{s}\left(\delta_{i j}-n_{i} n_{j}\right) d a+\int_{A_{g b}} \gamma_{g b}\left(\delta_{i j}-n_{i} n_{j}\right) d a\right\}
\end{aligned}
$$

ここで, $V^{*}=1 / \rho$ は比体積で相対密度の逆数, $n_{i}$ は表面の単位 法線ベクトル, 右辺第 2 項のブラケットの中は表面エネル ギーテンソルと粒界エネルギーテンソルである.ここでは球 形ポアの表面曲率の符号を正と定義した.

焼結応力テンソルの静水圧成分は次式で与えられる ${ }^{23)}$.

$$
\sigma^{s}=\frac{\sigma_{i i}^{s}}{3}=\frac{\gamma_{s} \kappa}{V^{*}}+\frac{2 E}{3 V}
$$

ここで, $E=\gamma_{s} A_{s}+\gamma_{g b} A_{g b}$ は表面エネルギーと粒界エネルギー の総和である. 右辺第2 項は系のエネルギーを体積で割った もので, Laplace 応力に対応する. 静水圧成分 $\sigma^{\text {s }}$ は焼結にお ける体積収縮, 偏差成分 $\sigma_{i}-\sigma^{s}$ は異方的変形の熱力学的駆動 力となる.

異方的な微構造をもつ多孔体の例として, 面心正方対称構 造の場合の焼結応力テンソルの成分を単位格子の軸比 $c / a$ の 関数として Fig. 7 に示した ${ }^{13)} . c / a=1$ の場合, 焼結応力は等

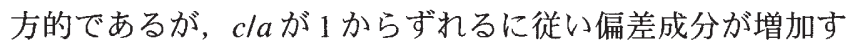
る. 焼結応力テンソルの偏差成分は粒子をより等軸形状に近 づける方向に作用する。

3.2 粘性テンソル

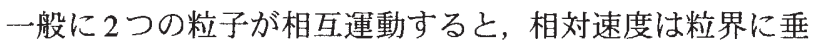
直な成分と平行な成分に分解できる. 粒界に垂直な運動は焼 結力により生じ, (12)式で記述できる. 粒界に粒界に平行な 運動, つまり, 粒界すべりに要するせん断応力はせん断ひず

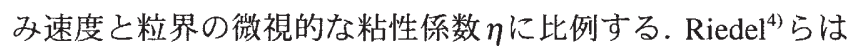
ひとつの粒子当たりの微視的なエネルギ一散逸と巨視的な変 形が行う仕事が等しいとして構成方程式((5)式)を導出し, 粘性 テンソル $C_{i j k m}$ を微視的な粒子配置の構造をもとに決定した.

彼らの方法は異方的な組織に応用できる ${ }^{13,24,25)}$. 等方組織の 場合独立な粘性テンソル成分は 2 個であるが, 立方対称の場 合 3 個，横等方性の場合 5 個，正方対称では 6 個となる. Fig. 8 に正方対称な局所構造に対する粘性テンソル成分を相対密度 の関数として示した ${ }^{13)}$. 図中に示すように相対密度とともに
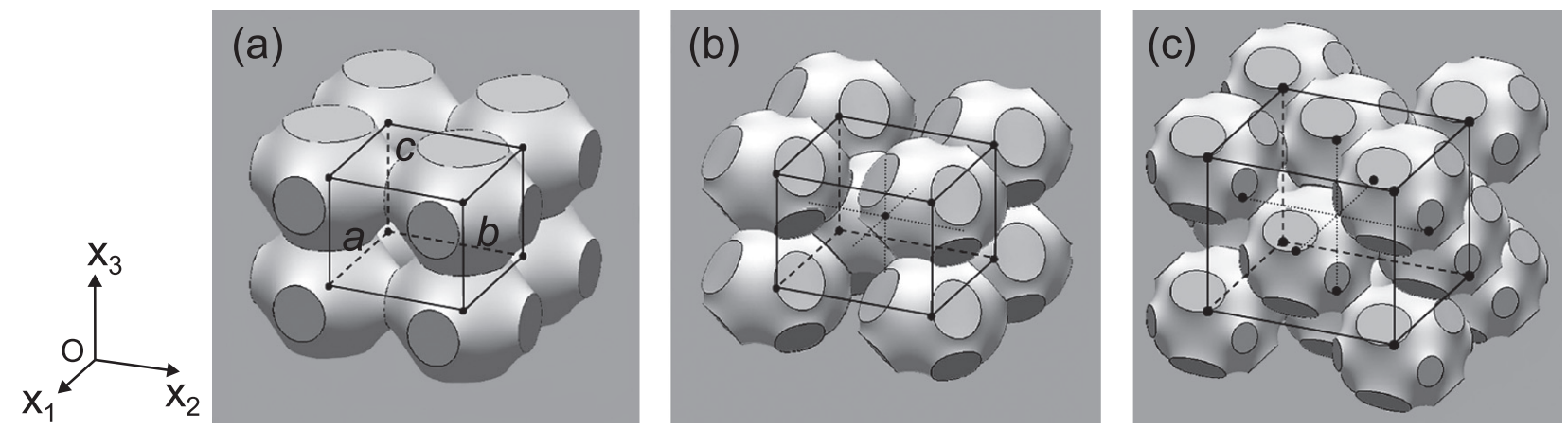

Fig. 6 Local arrangements of particles in open pore structures. (a) simple lattice, Coordination number $Z=6$, (b) body-centered lattice, $Z=8$, (c) face-centered lattice, $Z=12$. The Bravais lattices are formed with the particle centers ${ }^{22)}$. 


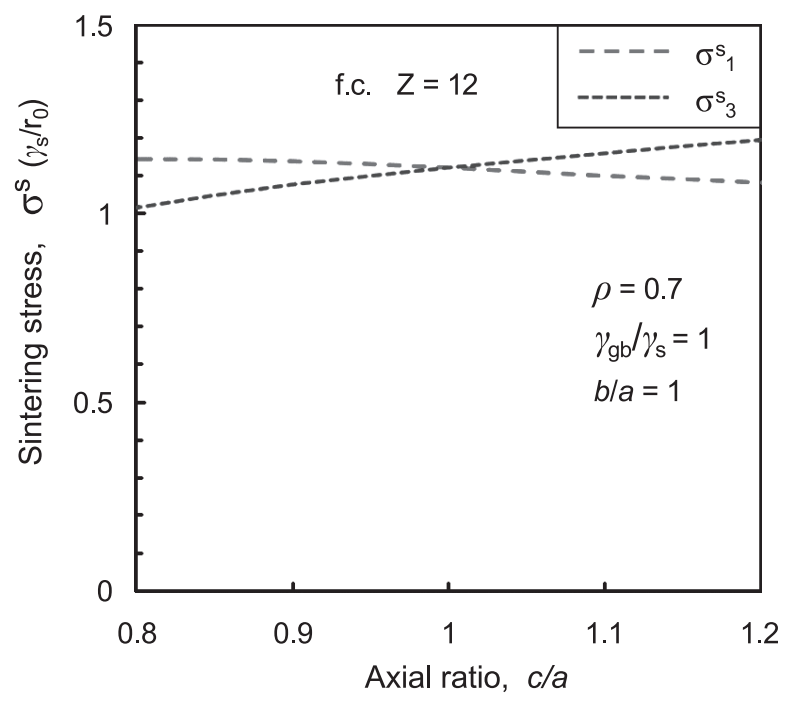

Fig. 7 Sintering stresses $\sigma_{i}^{s}$ for tetragonal structures as a function of the axial ratio $c / a^{13}$.

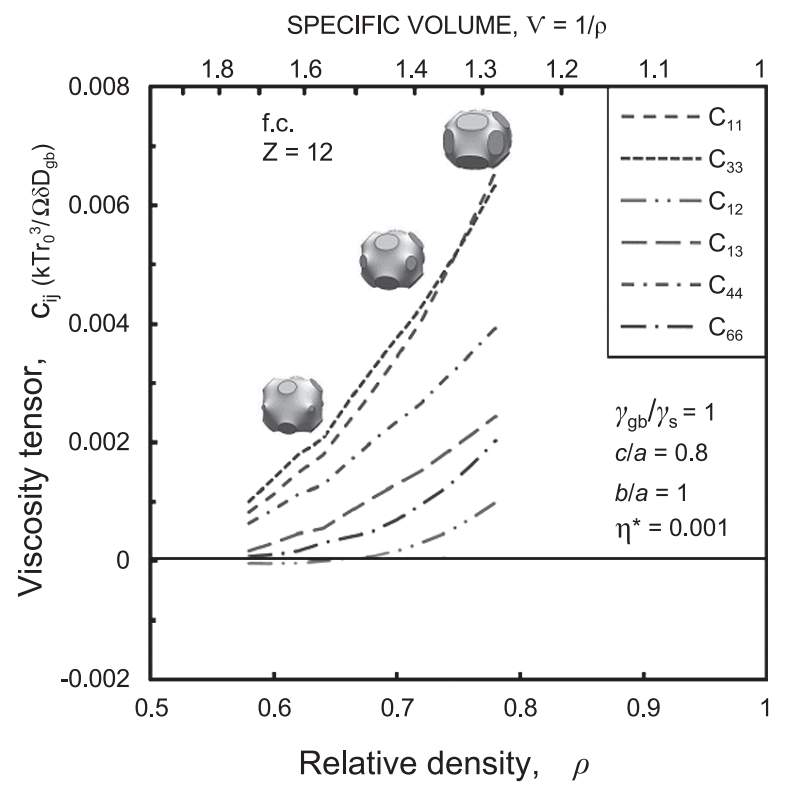

Fig. 8 Viscosity tensor $C_{i j}$ as a function of the relative density ${ }^{13)}$.

粒界面積は増加する. 粘性テンソルは粒界面積の自乗に比例 するので, 相対密度とともに増加する. 焼結のひず夕速度は 焼結応力と粘性テンソルから (5) 式により計算できる.

異方的な収縮は, 焼結応力テンソルよりも, 粘性テンソル の異方性に強く支配される. 異方的な収縮は微構造がより等 方的となる方向に起こる ${ }^{24)}$.

\section{3 等方組織の粘性係数}

立方対称組織の粘性テンソルをあらゆる方向から平均化す ることによって, ランダムな等方組織の粘性係数を推測でき る. Fig. 3 には $C_{i j}$ を平均化したVoigt モデルと， $S_{i j}$ を平均化 した Reuss モデル，及び，棈円体粒子集合体を仮定したセル

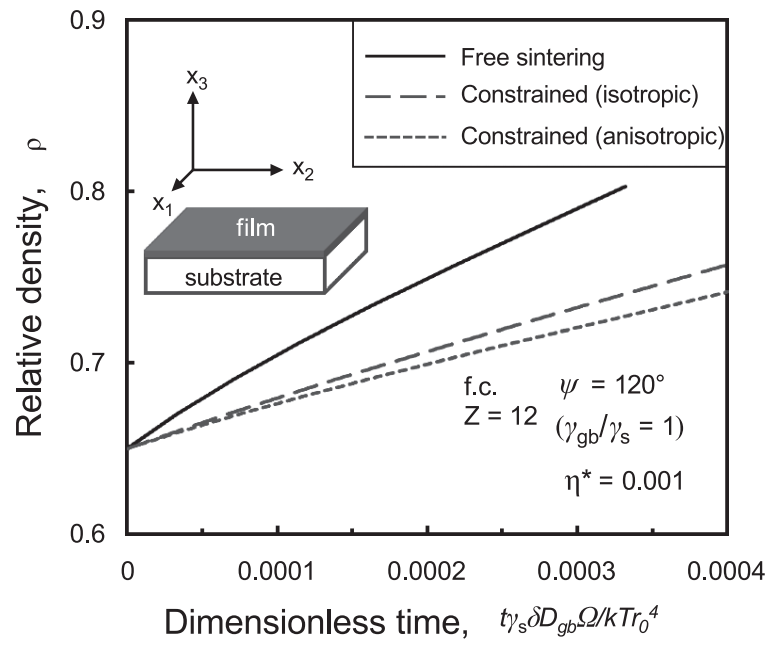

Fig. 9 Sintering of a constrained thin film on rigid substrate ${ }^{13)}$.

フコンシステントモデルから予測される粘性ポアソン比を示 した ${ }^{25)}$. セルフコンシステントモデルからの予想值は実測值 と良い一致を示した。

\section{4 拘束焼結における異方的微構造形成}

焼結のマルチスケールモデルの有用性を示す例として, 剛 体基板上の多孔質薄膜の拘束焼結について考える(Fig. 9). 薄 膜は $x_{1}-x_{2}$ 面内の収縮が基板から拘束 $\left(\dot{\varepsilon}_{1}=\dot{\varepsilon}_{2}=0\right)$ されるの で, 薄膜内には面内応力 $\left(\sigma_{1}=\sigma_{2}=\sigma^{\infty}\right)$ が発生する. (7), (8) 式 より面内応力は焼結応力の関数となる ${ }^{13)}$.

$$
\sigma^{\infty}=\sigma_{1}^{s}+\frac{S_{13}}{S_{11}+S_{12}} \sigma_{3}^{s}
$$

面内応力は引張りであり，薄膜の緻密化を阻害する。拘束さ れた薄膜の厚さ方向のひずみ速度 $\dot{\varepsilon}_{3}^{\text {constr }}$ は, 拘束されない場合 のひずみ速度完系と異なる.

$$
\begin{aligned}
& \dot{\varepsilon}_{3}^{\text {consir }}=\dot{\varepsilon}_{3}^{f}+2 S_{13} \sigma^{\infty} \\
& \dot{\varepsilon}_{3}^{f}=-2 S_{13} \sigma_{1}^{s}-S_{33} \sigma_{3}^{s}
\end{aligned}
$$

この異方的な収縮のために薄膜内部の微構造自体も焼結と ともに異方的となる. Fig. 9には薄膜の異方的微構造形成まで 考慮した際の緻密化曲線を点線で示した ${ }^{13}$. 自由焼結の場合 の曲線(実線) と比較すると, 拘束により緻密化が著しく抑制 されることがわかる. 破線は拘束焼結においても微構造は等 方性を保つと仮定した場合の緻密化曲線である. 実際には異 方的微構造形成のために, 密度は等方モデルから予測される よりも低くなる.この結論は実験的に観察された結果と良い 一致を示す。

Fig. 10には時間とともに薄膜中の微構造の異方性が発達す る様子を示す. 体積要素の軸比 $c / a$ は緻密化とともに 1 から 0.8 まで減少する. 焼結応力 $\sigma_{1}^{s}$ と面内応力 $\sigma^{\infty}$ が緻密化の進行と ともに，どのように増加するかを予測できる. 


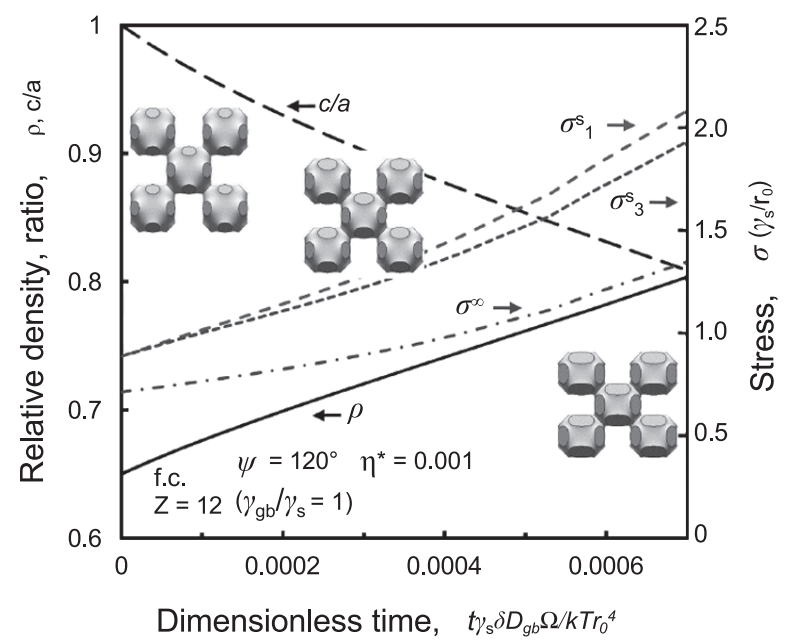

Fig. 10 Formation of anisotropic microstructure in constrained sintering of thin film ${ }^{13)}$.

\section{5 おわりに}

焼結力学のマルチスケールモデルは, 拘束焼結のような複 雑な焼結現象の実験結果を解釈する上で強力な道具となる. ここで紹介した理論体系は微構造がいかに異方的な収縮挙動 に影響するかを明らかにした. 現実の焼結では, 特に後期段 階で粒成長がおこる. 粒成長挙動がわかっていれば, その影 響を理論モデルに取り込んで, さらに拡張することも可能で ある、このような理論は, 焼結においてどのような要因を制 御することが重要なのかを判断するための指針を与える.し かしながら, 当然のことではあるが, 理論から導かれる洞察 が正しいかどうかは, 常に実験によって検証していく必要が ある。

\section{文献}

1) W.D. Kingery, H.K. Bowen, D.R. Uhlmann: Introduction to Ceramics, John Wiley \& Sons, Inc., New York, (1976).

2) R.M. German: Sintering Theory and Practice, Wiley, New York, (1996).

3) R.K. Bordia, G.W. Scherer: "On Constrained Sintering-I. Constitutive Model for Sintering Particle Packings", Acta Metall. Mater., 36(1988)2393-2397.

4) H. Riedel, H. Zipse, J. Svoboda: "Equilibrium Pore Surfaces, Sintering Stresses and Constitutive Equations for the Intermediate and Late Stages of Sintering-II. Diffusional Densification and Creep", Acta Metall. Mater., 42(1994)445-452.

5) A.C.F. Cocks: "The Structure of Constitutive Laws for the Sintering of Fine Grained Materials", Acta Metall. Mater., 42 (1994)2191-2210.

6) K. Shinagawa: "Finite Element Simulation of Sintering Process (Microscopic Modelling of Powder Compacts and Constitutive Equation for Sintering)", JSME Int.J., Ser. A, 39(1996)565-
572.

7) E.A. Olevsky: "Theory of Sintering: from Discrete to Continuum", Mater. Sci. Eng. R, 23(1998)41-100.

8) D.J. Green, O. Guillon, J. Rödel: "Constrained Sintering: A Delicate Balance of Scales", J. Euro. Ceram. Soc., 28(2008) 1451-1466.

9) T. Kraft, H. Riedel: "Numerical Simulation of Solid State Sintering; Model and Application", J. Euro. Ceram. Soc., 24 (2004)345-361.

10) R. Zuo, E. Aulbach, J. Rödel: "Viscous Poisson's Coefficient Determined by Discontinuous Hot Forging", J. Mater. Res., 18(2003)2170-2176.

11) A. Shui, Z. Kato, S. Tanaka, N. Uchida, K. Uematsu: "Sintering deformation caused by particle orientation in uniaxially and isostatically pressed alumina compacts", J. Euro. Ceram. Soc., 22(2002)311-316.

12) R.K. Bordia, R. Zuo, O. Guillon, S.M. Salamone, J. Rödel: "Anisotropic Constitutive Laws for Sintering Bodies", Acta Mater., 54(2006)111-118.

13) F. Wakai, R.K. Bordia: "Microstructural Evolution and Anisotropic Shrinkage in Constrained Sintering and Sinter Forging", J. Am. Ceram. Soc., 95(2012)2389-2397.

14) D.L. Johnson: "New Method of Obtaining Volume, GrainBoundary, and Surface Diffusion Coefficients from Sintering Data", J. Appl. Phys., 40(1969) 192-200.

15) W. Beere: "The Second Stage Sintering Kinetics of Powder Compacts", Acta Metall., 23(1975)139-145.

16) F. Wakai, K.A. Brakke: "Mechanics of Sintering for Coupled Grain Boundary and Surface Diffusion", Acta Mater., 59(2011) 5379-5387.

17) T. Rasp, C. Jamin, A. Wonisch, T. Kraft, O. Guillon: "Shape Distortion and Delamination During Constrained Sintering of Ceramic Stripes: Discrete Element Simulations and Experiments", J. Am. Ceram. Soc., 95(2012)586-592.

18) C.L. Martin, R.K. Bordia: "The effect of a substrate on the sintering of constrained films", Acta Mater., 57(2009)549-558.

19) B. Henrich, A. Wonisch, T. Kraft, M. Moseler, H. Riedel: Acta Mater., 55(2007)753-762.

20) J. Svoboda, H. Riedel, H. Zipse: "Equilibrium Pore Surfaces, Sintering Stresses and Constitutive Equations for the Intermediate and Late Stages of Sintering-I. Computation of Equilibrium Surfaces", Acta Mater., 42(1994)435-443.

21) K. Shinagawa: "Micromechanical modeling of viscous sintering and a constitutive equation with sintering stress", Comp. Mater. Sci., 13(1999)276-285.

22) F. Wakai, Y. Shinoda: "Anisotropic Sintering Stress for Sintering of Particles Arranged in Orthotropic Symmetry", Acta Mater., 57(2009)3955-3964.

23) F. Wakai, Y. Shinoda, T. Akatsu: "Methods to Calculate 
Sintering Stress of Porous Materials in Equilibrium", Acta Mater., 52(2004)5621-5631.

24) F. Wakai, T. Akatsu: "Anisotropic Viscosities and Shrinkage Rates in Sintering of Particles Arranged in a Simple Orthorhombic
Structure", Acta Mater., 58(2010)1921-1929.

25) F. Wakai, Z.S. Nikolić: "Effect of Grain Boundary Sliding on Shear Viscosity and Viscous Poisson's Ratio in Macroscopic Shrinkage during Sintering", Acta Mater., 59(2011)774-784. 